\title{
A Correlational Study Between Writing Interest, Vocabulary Mastery, and Writing Skill
}

\author{
Mahmud Al Habyby, Martono, Teguh Sarosa \\ English Education Department \\ Teacher Training and Education Faculty \\ Sebelas Maret University of Surakarta
}

Email: mahabyby@gmail.com

\begin{abstract}
The study is aimed to find out the correlation between (1) writing interest; (2) vocabulary mastery; and (3) writing skill of the tenth grade students at one of state senior high school in Surakarta, both partially and simultaneously. This study used test and questionnaire to collect the data. For the test, there are three kinds of test, those are objective test, oral test, and essay test. The method used in this study is correlation study. The techniques used to analyze the data are single and multiple correlation and also regression by using SPSS 17. The results of the study show that in the level of significance $\alpha=0.05$ (1) there is a positive correlation between writing interest and writing skill $\left(\mathrm{r}_{\mathrm{x} 1 \mathrm{y}}=0.680>\mathrm{r}_{\mathrm{t}}=0.339\right)$;(2) there is a positive correlation between vocabulary mastery and writing skill $\left(r_{x 2} y=0.846>r_{t}=0.339\right)$; and (3) there is a positive correlation between writing interest and vocabulary mastery simultaneously and writing skill $\left(\mathrm{R}_{\mathrm{y} 12}\right.$ is 0.889 and $\left.\mathrm{F}_{\mathrm{o}}=58.692>\mathrm{F}_{\mathrm{t}}=3.32\right)$. The positive correlation indicates that writing interest and vocabulary mastery tend to go up or to go down together with student's writing skill.
\end{abstract}

Keywords: writing interest, vocabulary mastery, writing skill

\section{INTRODUCTION}

Nowadays, English plays an important role for human life. Every progress of human life is related to English. Many textbooks, journals, scientific reports with various themes are written and translated in English. As an international language, English has been learnt by many peoples in the world. They are really aware that learning English brings many advantages in many aspects. Because of the importance of English, the Indonesian government has determined it as the first foreign language taught in Indonesia. It is a crucial subject in Senior High School, Junior High School, and Elementary School. Recently, it has been taught in Kindergarten too.
Brown (2001: 232) says that research and practice in English language teaching has identified the "four skills" (listening, speaking, reading, and writing) as of paramount importance. Compared to the other three language skills (listening, speaking, and reading), writing is considered as the most difficult skill for some students. It happens because to have a good writing, student should be careful in so many aspects, such as: the construction, ideas, word choice, spelling, punctuation, and good grammar development.

Writing plays an important role in everyday life. Brown (2004: 218) states that nowadays, the ability of writing are needed in our global literate community. When we 
are continuing our study to the higher level or when we are applying for a job, we need to make a curriculum vitae and an application letter. It has an important role to consider. The diction and the skill that is used to arrange the curriculum vitae and application letter will influence the consideration of acceptance. Of course the one who has a good writing will be more considered. Besides, writing is needed in making essay, reports, researches, and much other importance.

Writing is considered as the most difficult skill to learn for some students. As we know, it is not a natural skill. So it will not come easily and automatically. It is also a complicated skill because it needs many aspects to make a good writing. Based on Nunan (1989: 36) says "writing is an extremely complex cognitive activity in which the writer is required to demonstrate control of a number of variables simultaneously. At the sentence level these include control of content, format, sentence structure, vocabulary, punctuation, spelling, and letter formation."

Based on the definition above, writing is then defined as someone's skill to express ideas using graphic symbol in written language that have to be arranged according to certain conventions and linked together in certain ways, in order to form a coherent which can be understood by the readers.

In order to be able to express their idea in written form, students should master some elements of language, one of them is vocabulary. Nunan (1991: 118) says that, the development of a rich vocabulary is an important element in mastering a second language. It is important for a learner to master the vocabulary of the target language because it is essential part of communication. It means that learning language cannot be separated from vocabulary.

Richards (2001: 4) states that vocabulary is one of the most important components of language and one of the first things applied linguists turned their attention to. Vocabulary is the key aspect of language learning. Student will find difficulties if they have limited vocabulary. It will make the students unable to use the structure and functions they have learned for communication. Vocabulary is not only the knowledge of word meaning, but also the skill to determine the word forms, make the decision to choose the right words, expression, and spell them correctly.

Vocabulary cannot be separated from language skills. It plays an important role for understanding the language. Linse (2005: 121) says vocabulary is the collection of words that an individual knows. Vocabulary consists of noun, verbs, adjective, adverbs, preposition, articles, etc. Another statement is started by Hatch and Brown (1995: 1) who say that vocabulary refers to a list or set of words that individual speakers of language might use.

From the definition above we can conclude that vocabulary mastery is a complete knowledge of a list or a set of words with their meaning for a particular language used by individual or group of people, either in oral or written form of communication.

Another aspect which may influence writing skill is their writing interest. Interest is one of the important things for the success of one's activity. It motivates someone to be more active. Hurlock (1978: 420) says that interests are sources of motivation which drive people to do what they want to do when they are free to choose. Having a good interest is strengthened by a positive attitude 
toward a certain object will be able to dig someone's interest.

Writing interest gives much influence for students writing skill because by having interest in writing, it will motivate him to do writing by their desirability. Writing interest appears when a person has a need to write, so whether it is realized or not, he must have interest toward the things being needed in writing. According to Petty and Jensen (1980: 362) writing is the mental and physical act of forming letters and words. But it is much more than that, it is putting words into sentences, sentences into paragraphs, spelling word correctly, punctuating and capitalizing in customary ways, and observing conventions in written forms and more. So, it is a process of expressing thought and feelings of, thinking, and shaping experiences. It means that, when students have writing interest, they will feel free without any circumstance to write.

From the definition above, it can be concluded that writing interest is a source of motivation, which organized through experience to express thoughts and feelings in written form by putting words into sentences, and sentences into paragraphs. Writing interest is one's consciousness to learn more about writing activity. Writing interest appears when a person has a need to write, so whether it is realized or not, he must have interest toward the things being needed in writing.

\section{RESEARCH METHODS}

The method used in this study is correlation. According to Fraenkel (2008: 327) correlation is a study which investigates the possibility of relationship between two or more variables. It is not only concerned with data gathering but also with identifying and predicting relationships between the variables. This research is one of quantitative research which measure on two or more variables. The reason of choosing this method is the researcher wants to know the level of correlation between two or more variables based on statistic quantitative in correlation coefficient.

This research has two kinds of variables, independent variable and dependent variable. The independent variables in this research are writing interest (X1) and vocabulary mastery (X2). The dependent variable is writing skill (Y).

This research was carried out at one of state senior high school in Surakarta, which was conducted to the tenth grade students of in the academic year of 2012/2013. The sample of the study is 34 students taken by cluster random sampling technique.

The data are collected by using questionnaire and test. The questionnaire is used to collect the data of writing interest (which consists of 30 items having five alternatives answer), while the test are used to collect vocabulary mastery data (in the form of multiple choice test which consists of 42 items and oral test which consist of 10 items) and writing skill data. In this study, the validity and the reliability of all items of each instrument above have been tried out. The validity test is using bi-serial point correlation formula and the reliability test is using Kuder-Richardson for multiple choice instrument (the discrete score) and Alpha Croanbach for questionnaire instrument (continuum score).

The technique which is used to analyze the data was Linear Regression Analysis Statistic. The researcher tests the hypothesis using Product Moment and Multiple Linear Regression Formula. Product Moment Formula is used to describe the strength of relationship between two variables (single correlation), while 
Multiple Linear Regression is used to describe the strength between several independents variables and one dependent variable (multiple correlation). Before entering Linear Regression Analysis, there is major pre-requirement analysis for the data. They are normality test using Lilliefors formula, linearity and significance using Anova test.

\section{RESEARCH FINDINGS AND DISCUSSIONS}

From the testing of the first hypothesis, it is known that there is a positive correlation between writing interest and writing skill is accepted. The first hypothesis finds that the computation of analysis regression $\mathrm{X}_{1}$ and $\mathrm{Y}$, it is found that coefficient $\mathrm{a}=13.115$ and $\mathrm{b}=1.328$; so. The equation of regression is $Y=13.115+$ $1.328 \mathrm{X}_{1}$. The significance of regression is found that $F_{o}=66.47$, and $F_{t}=4.17$. Because $\left(F_{o}=66.47>F_{t}=4.17\right)$, so the regression of $\mathrm{X}_{1}$ and $\mathrm{Y}$ is significant. In the level of significance $\alpha=0.05$ and degree of freedom ( $\mathrm{df}=13: 19$ ) it is found that $\mathrm{F}_{t}$ is 2.56 . Because $\left(F_{o}=0.32<F_{t}=2.56\right)$. So, the equation of $\hat{Y}=13.115+1.328 \mathrm{X}_{1}$ is linier and significant.

Because the equation above is linier and significant, it can be used to predict the correlation between writing interest $\left(\mathrm{X}_{1}\right)$ and writing skill (Y). The coefficient of correlation is $r_{x 1 y}=0.680$. Then, this value is compared to r-table at the significance level of $5 \%$ for $\mathrm{N}=34$, it is 0.339 . This means that $\mathrm{r}$ observation is greater than $\mathrm{r}$ table $\left(\mathrm{r}_{\mathrm{x} 1 \mathrm{y}}\right.$ $\left.=0.680>r_{t}=0.339\right)$ and it is about $31.83 \%$. So there is a positive correlation between writing interest $\left(\mathrm{X}_{1}\right)$ and writing skill $(\mathrm{Y})$.

Writing interest is one of the important things for the success of one's activity. Syahid (2010: 109) says that writing interest is someone's cognitive and affective willingness to have attention and feeling for some activities, which order someone mentally and physically to express thoughts and feelings by arranging words into a sequence of arranged sentences, organizing the development of ideas or information, paying attention to the choice of vocabulary, grammatical patterns, and sentence structures, observing conventions in written forms to create a feasible meaning and an appropriate style to the subject matter and reader. If someone is not interested in writing, he or she will not be hoped to get success in writing. But if he is interested in writing, so his writing will be better because he will feel free to write what he wants to write.

Writing interest is one's consciousness to learn more about writing activity. Writing interest appears when a person has a need to write, so whether it is realized or not, he must have interest toward the things being needed in writing. The analysis result above is there is a positive correlation between writing interest and writing skill. It means that the increase of student's writing interest is followed by the increase of writing skill.

From the testing of the second hypothesis, it is known that there is a positive correlation between vocabulary mastery and writing skill is accepted. The second hypothesis finds that the computation of analysis regression $X_{2}$ and $\mathrm{Y}$, it is found that coefficient $\mathrm{a}=21.444$ and $\mathrm{b}=0.732$; so, the equation of regression is $Y$ $=21.444+0.732 \mathrm{X}_{2}$. The significance of regression is found that $\mathrm{F}_{\mathrm{o}}=22.15$, and $\mathrm{Ft}=$ 4.17. Because $\left(F_{o}=22.15>F t=4.17\right)$, so the regression of $\mathrm{X}_{2}$ and $\mathrm{Y}$ is significant. In the level of significance $\alpha=0.05$ and degree of freedom ( $\mathrm{df}=14: 18)$ it is found that $\mathrm{Ft}$ is 2.33. Because $\left(F_{o}=1.6<F t=2.33\right)$. So, the equation of $\hat{Y}=21.444+0.732 \mathrm{X}_{2}$ is linier and significant. 
Because the equation above is linier and significant, it can be used to predict the correlation between vocabulary mastery $\left(\mathrm{X}_{2}\right)$ and writing skill $(\mathrm{Y})$. The coefficient of correlation is $r_{x 1 y}=0.846$. Then, this value is compared to r-table at the significance level of $5 \%$ for $\mathrm{N}=34$, it is 0.339 . This means that $\mathrm{r}$ observation is greater than $\mathrm{r}$ table $\left(\mathrm{r}_{\mathrm{x} 1 \mathrm{y}}\right.$ $=0.846>\mathrm{r}_{\mathrm{t}}=0.339$ ) and it is about $47.27 \%$. So, there is a positive correlation between vocabulary mastery $\left(\mathrm{X}_{2}\right)$ and writing skill (Y).

The first thing that students need to have when they want to write is vocabulary. If they have limited vocabulary, they will not be able to extend the meaning. Students will confuse and sometimes make them misinterpret the meaning. Linse (2005: 121) says vocabulary is the collection of words that an individual knows. Vocabulary consists of noun, verbs, adjective, adverbs, preposition, articles, etc.

Another statement is stated by Hatch and Brown (1995: 1) who say that vocabulary refers to a list or set of words that individual speakers of language might use. Because vocabulary is central of language so the component of any language and the success in learning language can be proved by the success in mastering vocabulary. The analysis result above is there is a positive correlation between vocabulary mastery and writing skill. It means that the increase of vocabulary mastery is followed by the increase of writing skill.

From the testing of the third hypothesis, it is known that there is a positive correlation between writing interest, vocabulary mastery simultaneously, and writing skill is accepted. The third hypothesis finds that from the computation of multiple regressions. It is found that the coefficients of $\mathrm{a}_{0}, \mathrm{a}_{1}, \mathrm{a}_{2}$ are 2.250, 0.435, and 0.586. Therefore, the multiple regression equation of $\mathrm{Y}$ on $\mathrm{X}_{1}$ and $\mathrm{X}_{2}$ becomes; $Y=2.250+0.435 \mathrm{X}_{1}+0.586 \mathrm{X}_{2}$. The testing result of the significance of regression for $F_{o}$ is 58.692. This result is compared to $\mathrm{F}$ Table at the significance level of $5 \%$ and degree of freedom ( $\mathrm{df}=$ $2: 31)$ is 3.32. It means that $F_{o}(58.692)$ is higher than $\mathrm{F}_{\mathrm{t}(2: 31)}(3.32)$, so $\mathrm{F}_{\mathrm{o}}$ is significant. It shows that the equation of $Y=2.250+$ $0.435 \mathrm{X}_{1}+0.586 \mathrm{X}_{2}$ is linier and significant.

Because the equation is linier and significant so, it can be used to predict the correlation between students' writing interest $\left(\mathrm{X}_{1}\right)$ and vocabulary mastery $\left(\mathrm{X}_{2}\right)$ simultaneously and writing skill $(\mathrm{Y})$. The coefficient of correlation $\left(\mathrm{R}_{\mathrm{y} 12}\right)$ is 0.889 and $\left(\mathrm{R}^{2}\right)$ is 0.791 and it is about $79.1 \%$. The significance testing of this coefficient in $\mathrm{F}_{\mathrm{o}}$ is significant, so $\left(\mathrm{R}_{\mathrm{y} 12}\right)=0.889$ is also significant. Thus, the hypothesis stating that there is positive correlation between writing interest, vocabulary mastery, and writing skill is accepted. The conclusion is that there is positive correlation between writing interest and vocabulary mastery simultaneously and writing skill.

Based on Harris (1993: 11) "writing is a process that occurs over a period of time, particularly if we take into account, there sometimes extended periods of thinking that precede creating an initial draft." Furthermore, he also states (1993: 122) that writing is a complex activity. It is of fundamental importance to learning, to personal development, and to achievement in the education system. Teachers need to strive continually to find the best way to help pupils find fulfillment as writers.

One of the factors that influence writing skill is writing interest. Interest is one of the important things for the success of one's activity. Hurlock (1978: 420) says that interests are sources of motivation 
which drive people to do what they want to do when they are free to choose. Writing interest will improve one's writing skill. Having pleasure feeling in writing will motivate the students to do the positive attitude and finally it makes interest to writing. If someone is not interested in writing, he or she will not be hoped to get success in writing. But if he or she is interested in writing, so his or her writing will be better.

Vocabulary is also one of the points that must be mastered to get good writing skill. Haycraft (1978: 44) states that although someone knows many language terms without understanding the structure, idioms, and expression to carry it, it does not bring the mastery of a language, and that is why vocabulary is important. If people have mastered an adequate amount of vocabulary, so the communication will run smoothly.

Learning vocabulary in context is a good way to help learners in writing. Vocabulary is central of language in which it is the component of any language and the success in learning language can be proved by the success in mastering vocabulary. If learners have good vocabulary mastery, they can improve their writing skill.

Therefore, it can be concluded that there is a significant correlation between writing interest, vocabulary mastery simultaneously, and writing skill. So, writing interest and vocabulary are important factors in writing skill. And the result is there is positive correlation between writing interest $\left(\mathrm{X}_{1}\right)$ and vocabulary mastery $\left(\mathrm{X}_{2}\right)$ simultaneously toward writing skill (Y).

\section{CONCLUSIONS AND SUGGESTIONS}

From the result of the study, the researcher describes some conclusion. First, there is significant, positive correlation between writing interest and writing skill of students $\left(r_{x 1 y}=0.680>r_{t}=0.339\right)$ and it is about $79.1 \%$. It means that the increase of writing interest will be followed by the increase of writing skill.

Second, there is significant, positive correlation between vocabulary mastery and writing skill of the tenth grade students $\left(\mathrm{r}_{\mathrm{x} 2 \mathrm{y}}\right.$ $\left.=0.846>r_{t}=0.339\right)$ it is about $47.27 \%$. It means that the increase of vocabulary mastery will be followed by the increase of writing skill.

Third, there is significant, positive correlation between writing interest, vocabulary mastery simultaneously towards writing skill of the students $\left(\mathrm{R}_{\mathrm{y} 12}\right.$ is 0.889 and $\left.F_{o}=58.692>F_{t}=3.32\right)$ and it is about $79.1 \%$. It means that the increase of writing interest and vocabulary mastery will be followed by the increase of writing skill.

Based on the conclusion above, teacher should motivate the students to write a lot in order to increase the writing interest. Writing interest will be formed when a student feel free to write and happens unconsciously. Teacher should make the creative, active, effective, and fun English learning. Teacher and parents should be creative to make writing activity become interesting so that the students feel enjoy to write. The facility should be provided at school and home so that the students easily can access the sources to write.

Teacher should help the students to enrich their knowledge of vocabulary in order to help the students get success in writing. Teacher should improve their professional skill, especially in vocabulary. It can be through formal education, upgrading, training, and workshop. The students also should do many exercises about vocabulary mastery to achieve good writing. Students should improve their 
vocabulary mastery through writing and other activity because it is very important element in writing skill. For other researcher, there are many factors which can influence writing skill. Writing interest and vocabulary mastery are some factors that influence writing skill. However, there must be other factors which have contribution to writing skill. Therefore, the writer hopes that this research can be used as a reference for other researcher to do the related research, especially study which is related to writing skill.

\section{BIBLIOGRAPHY}

Brown, H. Douglas. 2001. Teaching by Principles. New York: Addison Wesley Longman, Inc.

Brown, H. Douglas. 2004. Language Assessment: Principles and Classroom Practices. New York: Pearson Education, Inc.

Fraenkel, Jack R. and Wallen, Norman E. 2008. How to Design and Evaluate Research in Education . Boston: McGraw-Hill.

Harris, John. 1993. Introducing Writing. London: The British Counsil.

Hatch, Evelyn. and Brown, Cheryl. 1995. Vocabulary, Semantics and Language Education. Cambridge. Cambridge University Press.

Haycraft, John. 1978. An Introduction to English Language Teaching. England: Longman.

Hurlock, Elizabeth B. 1978. Child Development. New York: McGraw Hill.

Linse, Caroline. 2005. Practical English Language Teaching: Young Learner. New York: McGraw Hill.
Nunan, David. 1991. Language Teaching Methodology. New York: Prentice Hall.

Petty, Walker T. and Jensen, Julie M. 1980. Developing Children's' Language. Boston: Allyn and Bacon.

Richard, Jack S. 2001. Curriculum Development in Language Teaching. Cambridge. Cambridge University Press.

Syahid, Abdul. 2010. A Comparative Study on Teaching Writing by Paper Based Portfolio Learning and Electronic Based Portfolio Learning Viewed from Writing Interest. Surakarta 